\title{
Postnatal growth of gut and muscle: competitors or collaborators
}

\author{
BY P. J. REEDS, D. G. BURRIN, T. A. DAVIS AND \\ M. L. FIOROTTO \\ USDA/ARS Children's Nutrition Research Center, Department of Pediatrics, 1100 Bates, \\ Houston, Texas 77030, USA
}

Although growth and functional maturation are essentially continuous from conception to the attainment of sexual maturity, birth and weaning are particularly critical milestones in life. Birth is associated with a change in the route of nutrient delivery to the organism and weaning requires the attainment of full locomotor function as the organism is called upon to actively seek its own food. Weaning is associated also with major changes in the composition of the diet, changes which in their turn demand intestinal adaptation. Given this, the tissues responsible for the assimilation of nutrients and the tissues responsible for mobility must grow and develop rapidly during the immediate postnatal period. Table 1 summarizes information on the growth rates of the body, intestinal tract, liver, and the leg muscles of the infant rat. Although the rat, as an altricial species, represents one extreme of the interspecific spectrum of chemical and functional maturation at birth, the information illustrates two general points. First, that as a reflection of the chemical maturation of the body, the rate of accretion of body protein exceeds that of the body mass as a whole. Second, that gut and muscle grow during the sucking period with rate constants that are significantly greater than that of body protein as a whole. We have included values for the liver to show that organs that have been of major physiological significance to the fetus tend to grow during the suckling period at a slower rate than that of the body protein mass as a whole.

Table 1. Fractional rates of growth $(\% / d)$ of the whole body and of different components of the body of immature rats*

\begin{tabular}{lccccc}
\hline & & \multicolumn{4}{c}{ Protein deposition (\%/d) } \\
\cline { 3 - 6 } Age (d) & $\begin{array}{c}\text { Body wt } \\
\text { (\%/d) }\end{array}$ & Body & Intestine & Muscle & Liver \\
\hline $4-10$ & 13 & 14 & 17 & 18 & 10 \\
$10-16$ & 9 & 11 & 8 & 14 & 7 \\
$16-28$ & 6 & 10 & 17 & 11 & 14 \\
\hline
\end{tabular}

* Values for muscle from Davis et al. (1991), for small intestine from Burrin et al. (1991) and for liver from Burrin et al. (1992a).

\section{OVERALL METABOLIC ACTIVITY}

We know that the overall level of metabolic activity in tissues of the gastrointestinal and skeletal muscular systems differ markedly between resting and active states. Thus, the values in Table 2 show that, despite a six-fourteenfold difference in their contributions to body mass, the contributions of the two tissues to overall energy expenditure in the quiescent state are essentially the same (Yen et al. 1989; Lobley, 1991). In ruminant 
Table 2. Estimated energy expenditure of the whole body, the portal-drained viscera $(P D V)$ and the skeletal muscle of the quiescent pig and sheep

\begin{tabular}{lccc}
\hline & Body & PDV & Muscle \\
\hline Pig* & 90 & 22 & 24 \\
mol ATP/d & $2 \cdot 81$ & $18 \cdot 1$ & $1 \cdot 6$ \\
mol ATP/kg per d & & 24 & 26 \\
\% total expenditure & $3 \cdot 6$ & 50 \\
g/kg body wt & 58 & & \\
Sheep & 1.65 & 20 & 19 \\
mol ATP/d & & 8.4 & $1 \cdot 1$ \\
mol ATP/kg per d & & 6.9 & 32 \\
\% total expenditure & & 40 \\
g/kg body wt & & \\
\hline
\end{tabular}

* PDV (Yen et al. 1989); muscle estimated from hind-quarter metabolism (Reeds et al. 1985).

$\dagger$ Summarized from Lobley (1991).

Table 3. Fractional rates of protein synthesis in tissues of immature rats*

\begin{tabular}{ccccc}
\hline & \multicolumn{4}{c}{ Protein synthesis $(\% / \mathrm{d})$} \\
\cline { 2 - 4 } & \multicolumn{2}{c}{ Leg muscles } & & \\
\cline { 2 - 4 } Age (d) & Phasic & $\begin{array}{c}\text { Tonic } \\
\text { (Type II) }\end{array}$ & $\begin{array}{c}\text { Small } \\
\text { intestine }\end{array}$ & Pancreas \\
\hline 5 & 31 & 34 & 50 & 100 \\
10 & 23 & 25 & 60 & 150 \\
16 & 23 & 30 & 60 & 150 \\
21 & 21 & 28 & 95 & 230 \\
28 & 16 & 20 & 110 & 300 \\
\hline
\end{tabular}

* Values for muscle taken from Davis et al. (1991) and those for the visceral organs from Burrin et al. (1991).

species, the contribution of the metabolic activity of the gastrointestinal tract exceeds that of the quiescent skeletal musculature, possibly as a result of the nature of the diets that they commonly consume (Lobley, 1991). Thus, a number of studies (e.g. Koong et al. 1983; Ferrell \& Koong, 1986; Burrin et al. 1990) have demonstrated that if large amounts of high-fibre diets are consumed, there is an increase in the contribution of the gastrointestinal tract to body mass and there are significant elevations in weight-specific rates of energy expenditure in the fasted state.

The same general comments apply to the respective contributions of gastrointestinal and skeletal muscle tissues to body protein mass and synthetic activity. Except during early postnatal life (Davis et al. 1989; Burrin et al. 1991; Table 3), the fractional rates of protein synthesis in the gastrointestinal and skeletal muscle mass differ by a factor of 5-10 (cf. McNurlan et al. 1979; Lobley et al. 1980; Simon et al. 1982; Garlick et al. 1983). Indeed, the difference is even greater if we include accessory tissues, such as the pancreas (Attaix et al. 1989; Burrin et al. 1991). It follows from these observations that the relative contributions of gastrointestinal and skeletal muscle to the growth of the 
organism as a whole affect not only the relationship between weight and basal metabolism, but also might influence the efficiency with which dietary energy (carbon) and protein are utilized for body lipid and protein gain.

\section{PROTEIN TURNOVER AND 'GROWTH'}

After weaning, approximately $50 \%$ of the total protein synthesized by the skeletal musculature is deposited as new muscle tissue while only $10 \%$ of the total protein synthesized by the gastrointestinal tract is accumulated as new mass. This observation is misleading, however, because the nature of postnatal growth in the two systems differs. Although there is some interspecific variation (see Sarkar et al. 1977; DiMarco et al. 1987), the mature number of myofibres is established in the perinatal period. It is generally held that the subsequent growth of the muscle mass occurs largely by hypertrophy of an existing population of fibres. New cells are recruited into these myofibres but many are from a population of cells that had developed during late fetal and early neonatal life. Postnatal muscle growth, therefore, is associated with a substantial increase in the protein:DNA value. In contrast, the cells of the intestinal crypts of Lieberkühn's proliferate throughout life, migrate along the villi, and are lost to the intestinal lumen. In this sense alone, the gastrointestinal tract grows continuously throughout the postnatal life of the organism. In weaned rodents, sheep and pigs the daily rate of cell migration and loss is approximately $25 \%$ of the population of villus enterocytes (Dauncey et al. 1983; Southon et al. 1985; Attaix \& Meslin, 1991), so that one-quarter of protein synthesis in the mucosa (and to some extent in the serosa; see Goldspink et al. 1984) is devoted to the production of new cells.

Another important functional difference between the two physiological systems is the high contribution of secretory activity to mucosal epithelial cell protein synthesis. These secretions take essentially three forms: first, the mucosa of the stomach and the exocrine pancreas secrete digestive enzymes continuously, especially during the suckling period when food is taken at frequent intervals. Second, throughout the gastrointestinal tract, significant quantities of mucus glycoproteins of variable carbohydrate and protein composition are secreted into the lumen and form a protective layer over the absorptive surface. Third, in the small intestine in particular, significant quantities of the enzymes responsible for the terminal stages of carbohydrate and protein digestion are synthesized in the endoplasmic reticulum and transported and inserted in the brush-border membrane of the villus enterocytes (Danielsen et al. 1984).

Only a small quantity of the extracellular digestive enzymes and mucins are stored in their cells of origin, so their fractional rates of synthesis can be exceedingly high (Table 3). For example, after weaning, the rat pancreas has an overall fractional rate of protein synthesis in excess of 300\%/d (Burrin et al. 1991). Furthermore, the fractional rate of synthesis of the brush-border proteins is considerably higher than the fractional rate of synthesis of total mucosal protein (James et al. 1971), and the hydrolases of the brush-border membrane are synthesized at a particularly high rate (Dudley et al. 1992). In the case of the brush-border proteins, the high rate of turnover is probably driven, at least in part, by the fact that this surface is subject to attrition from extracellular proteases. Thus, at least $30 \%$ of the overall protein synthetic activity of the small intestinal mucosa appears to be devoted to the elaboration of proteins that are lost rapidly into the intestinal lumen (Table 4); if we include cell turnover, the rate of 
Table 4. Distribution of protein synthetic activity of the upper intestinal tract of growing pigs*

\begin{tabular}{cccccc}
\hline Protein synthesis & & \multicolumn{3}{c}{ Secretory protein outflow $\dagger$} \\
\cline { 5 - 6 } \cline { 5 - 6 } Total $(\mathrm{g} / \mathrm{d})$ & Fractional $(\% / \mathrm{d})$ & & Total $(\mathrm{g} / \mathrm{d})$ & $\begin{array}{c}\text { Percentage of } \\
\text { protein pool }\end{array}$ & $\begin{array}{c}\text { Percentage of } \\
\text { protein synthesis }\end{array}$ \\
\hline 75 & 35 & 24 & 11 & 32 \\
\hline
\end{tabular}

* Protein synthetic values are the sum of pancreas, stomach, and small intestine (Simon et al. 1982).

$\dagger$ Outflow values taken from de Lange et al. (1990).

Table 5. Distribution of mucosal protein synthesis in fed adult rats*

\begin{tabular}{lcccc}
\hline & Total mucosa & Brush border & Cell loss & Cellular protein \\
\hline Total $(\mathrm{mg} / \mathrm{d})$ & 390 & 131 & 98 & 161 \\
Rate $(\% / \mathrm{d})$ & 125 & 420 & 25 & 40 \\
\hline
\end{tabular}

* Values for mucosal protein mass from Goldspink et al. (1984), for protein synthesis from McNurlan et al. (1982), Goldspink et al. (1984) and Dudley et al. (1992) and for brush-border turnover from Dudley et al. (1992); cell turnover time is taken as $4 \mathrm{~d}$.

synthesis of the constitutive proteins of the mucosal epithelium appear to be only $30-35 \% / d$ (Table 5). Thus, the term 'growth' as commonly applied, i.e. the accretion of new tissue, may well be inappropriate when we consider the gastrointestinal tract, and it could be argued that because of its secretory activity, a considerable proportion of mucosal protein synthetic activity is devoted to 'growth'. However, most of this protein synthesis is eventually lost to the intestinal lumen and represents a continual protein synthetic drain on the body. It has been argued (e.g. Reeds, 1990) that the failure to recapture intestinal secretions has a highly significant bearing on the magnitude of amino acid needs close to body protein equilibrium.

Although the skeletal musculature is not a secretory tissue, similar general comments apply with respect to the proportion of protein synthetic activity devoted to the elaboration of physiologically functional proteins. Approximately $50 \%$ of the total protein synthetic activity of mature skeletal muscle is devoted to the elaboration of myofibrillar proteins (Preedy \& Sugden, 1989), i.e. those inherent in the physiological function of the tissue. The ratio of the fractional rates of myofibrillar and sarcoplasmic synthesis varies not only with age, but does so in proportion to the relative rates of accretion of these two protein fractions (Table 6).

\section{NUTRITION AND THE GROWTH AND DEVELOPMENT OF GUT AND MUSCLE}

Changes in dietary composition and intake undoubtedly have many highly significant effects on the growth and function of tissues of the gastrointestinal tract and skeletal muscle. However, the interactions between organic nutrient intake and intestinal growth and function are potentially complex. There may well be interactions between the stage of development and the relationship between nutritional status, growth and protein 
Table 6. Changes in skeletal muscle myofibrillar and sarcoplasmic protein synthesis with age

(Mean values and standard deviations)

\begin{tabular}{|c|c|c|c|c|c|}
\hline \multirow[b]{3}{*}{ Age (d) } & \multicolumn{4}{|c|}{ Protein synthesis $(\% / d)$} & \multirow{3}{*}{$\begin{array}{l}\text { Myofibrillar: } \\
\text { sarcoplasmic }\end{array}$} \\
\hline & \multicolumn{2}{|c|}{ Myofibrillar } & \multicolumn{2}{|c|}{ Sarcoplasmic } & \\
\hline & Mean & SD & Mean & $\mathrm{SD}$ & \\
\hline 5 & 36 & 3 & 29 & 2 & 1.24 \\
\hline 10 & 33 & 2 & 19 & 2 & 1.73 \\
\hline 16 & 23 & 4 & 23 & 2 & 1.0 \\
\hline 35 & 11 & 2 & 17 & 3 & 0.65 \\
\hline
\end{tabular}

Values for suckling rats from M. L. Fiorotto, P. J. Reeds, D. G. Burrin and T. A. Davis (unpublished results) and those for 35-d-old rats from Preedy \& Sugden (1989).

metabolic activity. For example, various authors have emphasized (e.g. Waterlow et al. 1978; McNurlan et al. 1979) that after an overnight fast there is a marked difference in the degree to which protein synthesis is reduced in the small intestinal mucosa and muscle, and mucosal protein synthesis is relatively insensitive to short-term changes in food intake. However, when neonatal rats and pigs are fasted, the change in the rate of protein synthesis in the small intestine is as great as that in skeletal muscle (Burrin et al. 1991, 1992a; Davis et al. 1991).

The first point at which the composition of the diet could have a significant effect on tissue growth and maturation is immediately after birth. There is a substantial literature that suggests that growth and, by implication, maturation of some tissues of the neonate are stimulated by the ingestion of species homologous milk and especially colostrum. Thus, the ingestion of colostrum during the first $24 \mathrm{~h}$ after birth appears to advance, at least temporarily, the growth of the gastrointestinal tract (Widdowson et al. 1976; Hall \& Widdowson, 1979). This stimulatory effect is generally believed to be a response, at least in part, to the ingestion of trophic factors contained within mammary secretions (Klagsbrun, 1978; Heird et al. 1984; Berseth, 1987; Nichols et al. 1987; Francis et al. 1988). Although in some species, a significant proportion of early intestinal 'growth' after the consumption of colostrum represents the sequestration of milk proteins, especially IgG (Burrin et al. 1992b), the ingestion of colostrum acutely stimulates mucosal protein synthesis in both lambs (Patureau-Mirand et al. 1991) and pigs (Burrin et al. 1992b). Our recent work has demonstrated that the ingestion of colostrum during the first few hours after birth also stimulates protein synthesis in tissues other than those of the gastrointestinal tract, including skeletal muscle tissue (Burrin et al. 1992b; Table 7). Whether these effects on overall protein synthesis are also accompanied by an acceleration in maturation, as reflected in the expression of functionally important proteins, remains to be proven, but the possibility is exciting.

The interactions between changes in organic nutrient intake and growth beyond the immediate neonatal period are potentially more complex, especially in the gastrointestinal tract. Consideration of Table 1 , for example, reveals that in the rat the postnatal growth of the small intestine is rapid immediately after birth, slows at approximately $16 \mathrm{~d}$ post partum, and then rises at weaning. This growth pattern 
Table 7. Protein synthesis in the tissues of newborn piglets fed on water, mature sow's milk, and sow's colostrum $\dagger$

(Mean values and standard deviations)

\begin{tabular}{|c|c|c|c|c|c|c|}
\hline \multirow[t]{2}{*}{ Feeding group . } & \multicolumn{2}{|c|}{ Water } & \multicolumn{2}{|c|}{ Milk } & \multicolumn{2}{|c|}{ Colostrum } \\
\hline & Mean & SD & Mean & $\mathrm{SD}$ & Mean & SD \\
\hline & & & $\begin{array}{l}\text { Intes } \\
\text { ( } \mu \mathrm{mol} \text { pheny }\end{array}$ & $\begin{array}{l}\text { sue } \\
\mathrm{e} / \mathrm{kg} \mathrm{F}\end{array}$ & & \\
\hline \multirow{3}{*}{$\begin{array}{l}\text { Jejunum } \\
\text { Ileum }\end{array}$} & $4 \cdot 1$ & 0.5 & $11 \cdot 5$ & 0.8 & $12 \cdot 5$ & $1 \cdot 2$ \\
\hline & $2 \cdot 9$ & $0 \cdot 2$ & $8 \cdot 6$ & $0 \cdot 8$ & $11 \cdot 4 *$ & 0.7 \\
\hline & \multicolumn{6}{|c|}{ Non-intestinal tissue $(\% / d)$} \\
\hline Liver & 42 & 3 & 60 & 7 & $74^{*}$ & 4 \\
\hline Muscle & 13 & 2 & 17 & 2 & $26^{*}$ & 2 \\
\hline
\end{tabular}

Mean values were significantly higher than those for milk-fed animals: $* P<0 \cdot 05$.

$\dagger$ Values taken from Burrin et al. (1992b).

Table 8. Effects of preceding feed intake on contribution of gastrointestinal tissues to body weight ( $\mathrm{g} / \mathrm{kg}$ live weight)*

\begin{tabular}{|c|c|c|c|}
\hline Intake . . & Low & Medium & High \\
\hline Rats & $53 \cdot 1$ & $54-3$ & $65 \cdot 6$ \\
\hline Pigs & $34 \cdot 6$ & $39 \cdot 8$ & $48 \cdot 1$ \\
\hline Sheep: (a) & $71 \cdot 6$ & $73 \cdot 1$ & \\
\hline (b) & $57 \cdot 2$ & $66 \cdot 6$ & $67 \cdot 3$ \\
\hline
\end{tabular}

* Values for rats taken from Ferrell \& Koong (1986), those for pigs from Koong et al. (1983), and those for sheep from (a) Ferrell et al. (1986) and (b) Burrin et al. (1990).

illustrates the important influence of overall food (particularly solid matter) intake on the mass of the gastrointestinal tract. Evidence from studies of the relationship between early rodent growth and milk intake (Coward et al. 1982; Fiorotto et al. 1991) indicates that at approximately $16 \mathrm{~d}$ of postnatal age, milk intake becomes a significant limitation to the rate of overall weight gain; when expressed in terms of solid matter, the weight-specific feed intake at this age is probably as low as it will be until adulthood. As weaning is instituted, however, the high appetite of the very young animal, coupled with the ingestion of a diet containing substantial quantities of complex carbohydrates, leads to an increase in solid matter intake that is probably the highest that will be attained throughout the animal's life span. This time of maximum intake coincides with the time at which gut mass makes its largest contribution to body mass (Goldspink et al. 1984). The general relationships between intake and the mass of the intestine have been clearly demonstrated in a number of studies (Koong et al. 1983; Ferrell \& Koong, 1986; Burrin et al. 1990; Table 8). These studies show clearly that high intakes are associated with a high contribution of gastrointestinal mass to body mass and, as we pointed out earlier, these events coincide with an increase in the weight-specific rate of fasting heat production. 
Table 9. Effect of combined protein and energy restriction on visceral and carcass protein deposition in immature pigs and rats

\begin{tabular}{lccc}
\hline \hline & \multicolumn{2}{c}{ Rate of protein deposition (g protein/kg body-wt ${ }^{0.75}$ per d) } \\
\cline { 2 - 4 } & Control & Restricted & Percentage change \\
\hline Immature pigs (3.5-5 kg): & & & \\
$\quad \begin{array}{l}70 \% \text { restriction (Seve } \text { et al. 1986) } \\
\text { Intestine }\end{array}$ & 0.42 & 0.32 & -23 \\
$\quad$ Carcass & 2.84 & 0.19 & -93 \\
40\% restriction (S. Ebner and & & & \\
D. G. Burrin, unpublished results) & 0.34 & 0.26 & -23 \\
Intestine & 8.42 & 3.58 & -57 \\
Carcass & & & \\
Immature rats (11-15 g): & & -15 \\
25\% restriction (M. L. Fiorotto, P. J. Reeds, & & -23 \\
D. G. Burrin and T. A. Davis, unpublished results) & 0.22 & 0.18 & \\
Intestine & 6.71 & 5.16 & \\
Carcass &
\end{tabular}

A number of studies of very young animals has established that gastrointestinal mass, at low levels of intake, particularly of protein, makes a disproportionately high contribution to body protein deposition as a whole (Table 9). In this case, however, the differences in the protein gain of the different tissues do not reflect the stimulation of gastrointestinal growth as had occurred in the experiments summarized in Table 8 , but reflect the preservation of the intestine with either slow, or non-existent protein deposition in other components of the body, including the skeletal musculature. In fact, it appears that the preservation of protein deposition at the expense of lipid deposition in marginally nourished sucking animals (Fiorotto et al. 1991) extends to a hierarchy of tissue sensitivities; the gastrointestinal tract is relatively insensitive, the skeletal musculature shows some degree of sensitivity, and other tissues, particularly the skin and the liver, are especially sensitive to inadequate energy and protein intake.

During the immediate postnatal period, particularly in altricial mammals, substantial tissue maturation occurs in parallel with an increase in tissue mass. It is appropriate, therefore, to ask whether the nutritional regulation of the synthesis of proteins, whose function is to support the physiological demands of the body as a whole, is different from that of proteins whose prime function is the maintenance of the viability of cells in which they are synthesized. Present evidence poses a complex picture.

First of all, with respect to skeletal muscle protein turnover, evidence accumulated over the last decade suggests strongly that the sensitivity of the rates of degradation of myofibrillar and sarcoplasmic proteins to a variety of extracellular influences are not only quantitatively, but qualitatively different. The literature suggests that myofibrillar protein degradation is more sensitive to starvation (Lowell et al. 1986), protein intake (Goodman \& Gomez, 1987), insulin (Smith et al. 1989) and glucocorticoids (Kayali et al. 1987) than is the degradation of sarcoplasmic proteins. In contrast, studies of the stimulatory effects of functional overload (Gregory et al. 1990) and the inhibitory effects of fasting (Preedy \& Sugden, 1989) suggest that myofibrillar and sarcoplasmic protein synthesis are affected in similar proportions. 
Our recent findings suggest that the differential sensitivity of the degradation of the two protein 'pools' of muscle applies to the nutritional regulation of myofibrillar and sarcoplasmic protein deposition during early life. In a partially completed study, we (M. L. Fiorotto and M. Perez, unpublished results) have found that although muscle protein deposition was reduced to only a small extent $(-6 \%)$ in undernourished sucking rats, myofibrillar protein deposition was significantly $(-15 \%)$ lower while the deposition of the sarcoplasmic proteins had not been affected by undernutrition. These differences in deposition were associated with equally low rates of synthesis of both muscle protein pools $(-20 \%)$. The rate of sarcoplasmic protein degradation, however, was reduced by $50 \%$, but that of myofibrillar protein was only $30 \%$ lower than the rate in well-nourished pups. Whether these early effects of undernutrition on the relative rates of accretion of contractile and non-contractile proteins of skeletal muscle are permanent remains to be investigated, but they have substantial implications for overall functional development of the skeletal musculature of undernourished infants.

A separate issue with respect to the interactions between early nutrition and functional development relates to the maturation process itself. The gastrointestinal tract of young mammals shows a characteristic development pattern of disaccharidase activity. This pattern is characterized by high levels of the enzyme lactase ( $E C$ 3.2.1.108) in early life followed by the subsequent acceleration of sucrase (EC 3.2.1.48) expression (Henning, 1986). Similarly, in the skeletal musculature of altricial mammals, different myosin isoforms are expressed as development proceeds (Whalen et al. 1979). In both cases, development involves the appearance of new enzymes accompanied by a progressive fall in the concentration of proteins characteristic of the immature state. Interestingly, recent studies of the impact of severe undernutrition on the intestinal tract of the young pig (M. A. Dudley and W. G. Pond, unpublished results) and of the changes in myosin isoform expression in the skeletal musculature of immature rats (M. L. Fiorotto and $M$. Perez, unpublished results) suggest that undernutrition does not substantially inhibit the appearance of proteins characteristic of the mature state, but does retard the disappearance of proteins characteristic of the immature animal. Thus, early undernutrition does not retard functional development in regard to when developmentally regulated proteins appear, but, perhaps by restricting protein degradation, undernutrition leads to the persistence of proteins associated with the newborn state.

\section{CONCLUSION}

The skeletal musculature and the gastrointestinal tract are not only of great significance to the physiological function of the young organism, but their relative masses affect the efficiency with which the animal utilizes organic macronutrients. The consumption of diets containing high levels of complex carbohydrate and the consumption of inadequate diets containing relatively low levels of protein appear to cause exaggerated growth of the gastrointestinal tract. Such growth conceivably affects both basal energy expenditure and the energetic efficiency with which dietary $C$ is utilized for body protein and lipid accretion. It is possible that significant proportions of growth and functional regulation are intrinsic to the intestine, perhaps mediated by locally acting paracrine trophic factors elaborated by the lymphocytes and fibroblasts that are prominent within the mucosa, while postnatal muscle growth is regulated primarily by endocrine factors (such as insulin, corticosteroids and IGF-I) that circulate in the blood plasma. At the same time, 
the growth of skeletal muscle and, as suggested by preliminary evidence, the accretion of the functional proteins of skeletal muscle appear to be specifically sensitive to the level of intake. Thus, it is possible that the consumption of inadequate diets at or around weaning may influence the mobility of the developing organism and, in the case of animals, their ability to forage for food.

These remarks imply that the gastrointestinal tract and the skeletal musculature are in effect competitors for the disposition of nutrients available over and above those needed to maintain metabolic and physiological viability. This conclusion, however, is too simplistic. It is important to remember that the gastrointestinal tract represents an important barrier that protects the organism from invasion by pathogenic bacteria and other parasites. Furthermore, unless some degree of gastrointestinal function is maintained during undernutrition, the subsequent assimilation of nutrients from more adequate diets may be compromised temporarily. Thus, the relative preservation of gut mass may serve an important adaptive function. At the same time, the skeletal muscle in effect functions as a protein store from which amino acids, such as glutamine and arginine, can be drawn in times of stress to preserve immune and perhaps gastrointestinal function. In other words, what could be seen as a 'competition' is in fact a regulated 'collaboration' in which the compromise of some functions ensures the maintenance of the organism as a whole.

This work is a publication of the USDA/ARS Children's Nutrition Research Center, Department of Pediatrics, Baylor College of Medicine, Houston, TX. This project has been funded in part with federal funds from the US Department of Agriculture, Agricultural Research Service under Co-operative Agreement number 58-6250-1-003. The contents of this publication do not necessarily reflect the views or policies of the US Department of Agriculture, nor does mention of trade names, commercial products, or organizations imply endorsement from the US Government. The authors are grateful to E. R. Klein for her editorial advice.

\section{REFERENCES}

Attaix, D. E., Aurousseau, G., Bayle, D., Rosolowska-Huszcz, A., Manghebati, A. \& Arnal, M. (1989). Influences of age and weaning on in vivo pancreatic protein synthesis in the lamb. Journal of Nutrition 119 , $463-470$.

Attaix, D. \& Meslin, J.-C. (1991). Changes in small intestinal morphology and cell renewal in suckling, prolonged suckling and weaned lambs. American Journal of Physiology 261, R811-R818.

Berseth, C. L. (1987). Enhancement of intestinal growth in neonatal rats by epidermal growth factor in milk. American Journal of Physiology 253, G662-G665.

Burrin, D. G., Davis, T. A., Fiorotto, M. L. \& Reeds, P. J. (1991). Stage of development and fasting affect protein synthetic activity in the gastrointestinal tissues of suckling rats. Journal of Nutrition 121, 1099-1108.

Burrin, D. G., Davis, T. A., Fiorotto, M. A. \& Reeds, P. J. (1992a). Hepatic protein synthesis in rats, the effects of stage of development and fasting. Pediatric Research 261, 1373-1380.

Burrin, D. G., Ferrell, C. L., Britton, R. A. \& Bauer, M. (1990). Level of nutrition and visceral organ size and metabolic activity in sheep. British Journal of Nutrition 64, 439-448.

Burrin, D. G., Shulman, R. J., Reeds, P. J., Davis, T. A. \& Gravit, K. R. (1992b). Porcine colostrum and milk stimulate visceral organ and skeletal muscle protein synthesis in neonatal piglets. Journal of Nutrition 122 , 1205-1213.

Coward, W. A., Cole, T. J., Gerber, H., Roberts, S. B. \& Fleet, I. (1982). Water turnover and milk intake. Pflügers Archives 393, 344-347.

Danielsen, E. M., Cowell, G. M., Noren, O. \& Sjostrom, H. (1984). Biosynthesis of microvillar proteins. Biochemical Journal 221, 1-14. 
Dauncey, M. J., Ingram, D. L., James, P. S. \& Smith, M. W. (1983). Modification by diet and environmental temperature of enterocyte function in pig intestine. Journal of Physiology 341, 441-452.

Davis, T. A., Fiorotto, M. L., Burrin, D. G. \& Reeds, P. J. (1991). The response of muscle protein synthesis to fasting in suckling and weaned rats. American Journal of Physiology 261, R1373-R1380.

Davis, T. A., Fiorotto, M. L., Nguyen, H. V. \& Reeds, P. J. (1989). Protein turnover in skeletal muscles of suckling rats. American Journal of Physiology 257, R1141-R1146.

de Lange, C. F. M., Souffrant, W. B. \& Sauer, W. C. (1990). Real ileal and amino acid digestibilities in feedstuffs from growing pigs as determined with the ${ }^{15} \mathrm{~N}$-isotope dilution technique. Journal of Animal Science 68, 409-418.

DiMarco, O. N., Baldwin, R. L. \& Calvert, C. C. (1987). Relative contribution of hyperplasia and hypertrophy to growth in cattle. Journal of Animal Science 65, 150-159.

Dudley, M. A., Nichols, B. L., Rosenberger, J., Perkinson, J. S. \& Reeds, P. J. (1992). Feeding status affects in vivo prosucrase Isomaltase processing in rat jejunum. Journal of Nutrition 122, 528-534.

Ferrell, C. L. \& Koong, L. J. (1986). Influence of plane of nutrition on body composition, organ size and energy utilization of Sprague-Dawley rats. Journal of Nutrition 116, 2525-2535.

Ferrell, C. L., Koong, L. J. \& Nienaber, J. A. (1986). Effect of previous nutrition on body composition and maintenance energy costs of growing lambs. British Journal of Nutrition 56, 595-605.

Fiorotto, M. L., Burrin, D. G., Perez, M. \& Reeds, P. J. (1991). Intake and use of milk nutrients by rat pups suckled in small, medium or large litters. American Journal of Physiology 260, 1104-1113.

Francis, G. L., Upton, F. M., Ballard, F. J., McNeil, K. A. \& Wallace, J. C. (1988). Insulin like growth factors 1 and 2 in bovine colostrum. Biochemical Journal 251, 95-103.

Garlick, P. J., Fern, M. \& Preedy, V. R. (1983). The effect of insulin infusion and food intake on muscle protein synthesis in postabsorptive rat. Biochemical Journal 210, 669-676.

Goldspink, D. F., Lewis, S. E. M. \& Kelly, F. J. (1984). Protein synthesis during developmental growth of the small and large intestine of the rat. Biochemical Journal 217, 527-535.

Goodman, M. N. \& Gomez, M. D. P. (1987). Decreased myofibrillar proteolysis after refeeding requires dietary protein or amino acids. American Journal of Physiology 253, E52-E58.

Gregory, P. W., Gagnon, J., Essig, D. A., Reid, S. K., Prior, G. \& Zak, R. (1990). Differential regulation of actin and myosin isozyme synthesis in functionally overloaded muscle. Biochemical Journal 265, 525-532.

Hall, R. A. \& Widdowson, E. M. (1979). Response of the organs of rabbits to feeding during the first days after birth. Biology of the Neonate 35, 131-139.

Heird, W. C., Schwartz, S. M. \& Hansen, I. H. (1984). Colostrum-induced enteric mucosal growth in beagle puppy. Pediatric Research 18, 512-515.

Henning, S. J. (1986). Development of the gastrointestinal tract. Proceedings of the Nutrition Society $45,39-44$.

James, W. P. T., Alpers, D. H., Gerber, J. E. \& Isselbacher, K. J. (1971). The turnover of disaccharidases and brush border proteins in rat intestine. Biochimica et Biophysica Acta 230, 194-203.

Kayali, A. G., Young, V. R. \& Goodman, M. N. (1987). Sensitivity of myofibrillar proteins to glucocorticoidinduced muscle proteolysis. American Journal of Physiology 252, E621-E626.

Klagsbrun, M. (1978). Human milk stimulates DNA synthesis and cellular proliferation in cultured fibroblasts. Proceedings of the National Academy of Sciences, USA 75, 5057-5061.

Koong, L. J., Nienaber, J. A. \& Mersmann, H. J. (1983). Effects of plane of nutrition on organ size and fasting heat production in genetically lean and obese pigs. Journal of Nutrition 113, 1626-1631.

Lobley, G. E. (1991). Organ and tissue metabolism, present status and future trends. In Energy Metabolism of Farm Animals. European Association of Animal Production Publication no. 58, pp. 80-87 [C. Wenk and M. Boessinger, editors]. Zurich: Institute für Nutztierwissenschaften, ETH-Zurich.

Lobley, G. E., Milne, V., Lovie, J., Reeds, P. J. \& Pennie, K. (1980). Whole body and tissue protein synthesis in cattle. British Journal of Nutrition 43, 491-502.

Lowell, B. B., Ruderman, N. B. \& Goodman, M. N. (1986). Regulation of myofibrillar protein degradation in rat skeletal muscle during brief and prolonged starvation. Metabolism 35, 1121-1127.

McNurlan, M. A., Fern, E. B. \& Garlick, P. D. (1982). Failure of leucine to stimulate protein synthesis in vivo. Biochemical Journal 204, 831-838.

McNurlan, M. A., Tomkins, A. M. \& Garlick, P. J. (1979). The effect of starvation on the rate of protein synthesis in rat liver and small intestine. Biochemical Journal 178, 373-379.

Nichols, B. L., McKee, K. S., Henry, J. F. \& Putman, M. (1987). Human lactoferrin stimulates thymidine incorporation into DNA of rat crypt cells. Pediatric Research 21, 563-567.

Patureau-Mirand, P., Mosoni, L., Levieux, D., Attaix, D. \& Bonnet, Y. (1991). Effect of colostrum feeding on protein metabolism in the small intestine of newborn lambs. Biology of the Neonate 57, 30-36. 
Preedy, V. R. \& Sugden, P. H. (1989). The effects of fasting or hypoxia on rates of protein synthesis in vivo in subcellular fractions of rat heart and gastrocnemius muscle. Biochemical Journal 257, 519-527.

Reeds, P. J. (1990). Amino acid needs and protein scoring patterns. Proceedings of the Nutrition Society 49, 17-25.

Reeds, P. J., Fuller, M. F. \& Nicholson, B. A. (1985). Metabolic basis of energy expenditure with particular reference to protein. In Substrate and Energy Metabolism in Man, pp. 46-67 [J. S. Garrow and D. Halliday, editors]. London: John Libbey and Son.

Sarkar, N. K., Lodge, G. A. \& Friend, D. W. (1977). Hyperplastic and hypertrophic growth of the neonatal pig. Journal of Animal Science 46, 722-728.

Seve, B., Reeds, P. J., Fuller, M. F., Cadenhead, A. \& Hay, S. M. (1986). Protein synthesis and retention in some tissues of the young pig as influenced by dietary protein intake after early-weaning. Possible connection to the energy metabolism. Reproduction Nutrition and Development 26, 849-861.

Simon, O., Bergner, H., Munchmeyer, R. \& Zebrowska, T. (1982). Studies on the range of tissue protein synthesis in pigs, the effect of thyroid hormones. British Journal of Nutrition 48, 571-582.

Smith, O. L. K., Wong, C. Y. \& Gelfand, R. A. (1989). Skeletal muscle proteolysis in rats with acute streptozocin-induced diabetes. Diabetes 38, 1117-1122.

Southon, S., Livesey, G., Gee, J. M. \& Johnson, I. T. (1985). Differences in intestinal protein synthesis and cell proliferation in well-nourished rats consuming conventional laboratory diets. British Journal of Nutrition 53, 87-95.

Waterlow, J. C., Garlick, P. J. \& Millward, D. J. (1978). Protein Turnover in Mammalian Tissues and in the Whole Body. Amsterdam: North Holland.

Whalen, R. G., Schwartz, K., Bouveret, P., Sell, S. M. \& Gros, F. (1979). Contractile protein isoforms in muscle development, identification of an embryonic form of myosin heavy chain. Proceedings of the National Academy of Sciences, USA 76, 5197-5201.

Widdowson, E. M., Colombo, V. E. \& Artavanis, C. A. (1976). Changes in the organs of pigs in response to feeding for the first $24 \mathrm{~h}$ after birth. Biology of the Neonate 28, 272-281.

Yen, J. T., Nienaber, J. A. \& Pond, W. G. (1989). Oxygen consumption by portal vein-drained organs and by the whole animal in conscious growing swine. Proceedings of the Society for Experimental Biology and Medicine 190, 393-398. 